\title{
Teknologi Fermentasi Menggunakan Kapang Trichoderma sp untuk Meningkatkan Kualitas Nutrisi Kulit Kopi sebagai Pakan Ternak Ruminansia
}

\section{Fermentation Technology Using Molds Trichoderma sp to Improve the Quality of Nutrition of Coffee Skin as a Ruminant Feed}

\author{
Dewi Ratih Ayu Daning ${ }^{1}$, Artika Dowi Karunia ${ }^{2}$ \\ ${ }^{1}$ Dosen Sekolah Tinggi Penyuluhan Pertanian Malang \\ ${ }^{3}$ Mahasiswa Sekolah Tinggi Penyuluhan Pertanian Malang \\ e-mail: daningstpp@gmail.com
}

\begin{abstract}
ABSTRAK
Penelitian ini bertujuan untuk pemanfaatan limbah kulit kopi menggunakan Trichoderma $s p$ untuk meningkatkan kualitas nutrisi dari limbah kulit kopi. Manfaat fermentasi dengan teknologi ini antara lain meningkatkan kandungan protein, menurunkan kandungan serat kasar, menurunkan kandungan tannin. Metode yang digunakan dalam penelitian ini adalahTrichoderma starter diperoleh dari produk komersil Kulit kopi $(5 \mathrm{~kg})$, Air (60\% x $5 \mathrm{~kg}=3$ Liter untuk ciptakan kelembaban; 3\% x $5 \mathrm{~kg}=1,5$ Liter untuk larutan), Tetes tebu (3\% x 1,5 Liter $=150 \mathrm{ml})$, Trichoderma cair $(1 \%$ x $150 \mathrm{ml}=1,5 \mathrm{ml})$. Perlakuan diulang sebanyak 3 kali pembuatan diwaktu yang berbeda dan dibuat ulangan sebanyak 12 kantong plastic. Dari hasil penelitian teknologi fermentasi menggunakan kapang Trichoderma pada limbah kulit kopi yang telah dilaksanakan, diperoleh kesimpulan sebagai berikut: Sampel kulit kopi yang telah difermentasikan menggunakan kapang Trichoderma (cair) dominan berwarna kuning kecoklatan, memiliki tekstur yang kasar dan berbau asam segar; $\mathrm{pH}$ pada kulit kopi hasil fermentasi berkisar antara 4. Melalui analisis proksimat diperoleh hasil bahwa sampel kulit kopi yang telah difermentasikan menggunakan kapang Trichoderma (cair) memiliki kandungan protein sebesar 13,67\%, serat kasar sebesar 26,95\% dan lemak kasar 1,03\%.
\end{abstract}

Kata kunci-kulit kopi, fermentasi, Trichoderma sp, kualitas nutrisi

\section{ABSTRACT}

This study aims to use Trichoderma sp as starter fermentation to improve the quality of nutrients from coffee peel. The benefits of fermentation with this technology include increasing protein content, reducing crude fiber content, and reducing tannin content. The material and method used in this study is trichoderma starter obtained from commercial products, coffee waste (5 kg), water (60\% $55 \mathrm{~kg}=3$ liters to create moisture; $3 \% \times 5 \mathrm{~kg}=1.5$ liters for solution), sugarcane drops $(3 \% \times 1.5$ Liter $=150 \mathrm{ml})$, Trichoderma liquid $(1 \% \times 150 \mathrm{ml}=1.5 \mathrm{ml})$. The treatment was repeated 3 times at different times and 12 plastic bags were repeated. From the results of research on fermentation technology using Trichoderma on coffee waste that has been carried out, the following conclusions are obtained: Coffee samples that have been fermented using dominant Trichoderma (liquid) mold are brownish yellow, have a rough texture and smell fresh sour; The $\mathrm{pH}$ of fermented coffee peels ranged from 4. Through proximate analysis, the results showed that coffee skin samples fermented using Trichoderma (liquid) mold had a protein content of $13.67 \%$, crude fiber of $26.95 \%$ and crude fat of $1.03 \%$ 
Keywords - coffee peel, fermentation, Trichoderma sp, nutrient quality

\section{PENDAHULUAN}

Kopi termasuk tanaman yang menghasilkan limbah hasil sampingan yang cukup besar dari hasil pengolahannya. Limbah sampingan tersebut berupa kulit kopi yang jumlahnya berkisar antara 50-60\% dari hasil panen. Bila hasil panen sebanyak $1000 \mathrm{~kg}$ kopi segar berkulit, maka yang menjadi biji kopi sekitar 400-500 kg dan sisanya adalah hasil sampingan berupa kulit kopi (Tilawati, 2016). Limbah kulit kopi belum dimanfaatkan petani secara optimal. Padahal kulit kopi bisa dimanfaatkan sebagai pakan karena kulit kopi mempunyai kecernaan protein sebesar $65 \%$ dan 51,4\% untuk kulit biji (Azwar, 2012).

Kulit kopi cukup potensial untuk digunakan sebagai bahan pakan ternak ruminansia. Kandungan nutrisi kulit kopi non fermentasi seperti protein kasar sebesar 8,49\% (Ismayadi, 2000). Kulit kopi diberikan langsung dalam bentuk basah, kadar air yang cukup tinggi sehingga mudah rusak dan kurang disukai ternak. Selain itu tingginya kandungan serat kasar dan adanya kandungan tanin, kafein dan lignin pada kulit kopi non fermentasi dapat mengganggu pencernaan ternak jika diberikan dalam jumlah banyak. Salah satu cara untuk meminimalkan faktor pembatas tersebut, kulit kopi diolah terlebih dahulu sebelum diberikan kepada ternak (Djajanegara dan Sitorus, 1993), melalui teknologi fermentasi.

Peningkatan kualitas pakan dapat dilakukan melalui fermentasi menggunakan jamur Trichoderma. Bahan pakan yang difermentasi menggunakan limbah pertanian dapat menggantikan pakan hijauan pada musim kemarau. Limbah pertanian menjadi salah satu penyokong dalam pemenuhan kebutuhan pakan bagi ternak. Limbah pertanian dan perkebunan yang tidak dimanfaatkan dapat menjadi pakan alternatif misalnya limbah kakao, limbah wortel, dan kulit kopi. Fermentasi merupakan pengolahan secara biologi, yaitu pengolahan dengan memanfaatkan mikroorganisme yang akan menghasilkan enzim untuk melakukan perubahan terhadap molekul kompleks seperti protein, karbohidrat dan lemak menjadi molekul yang lebih sederhana. Mikroorganisme yang dapat digunakan untuk fermentasi adalah Trichoderma. Pemanfaatan kulit kopi dengan proses fermentasi diharapkan mampu meningkatkan potensi kulit kopi sebagai bahan pakan alternatif yang berkualitas tinggi dan dapat mempengaruhi kandungan protein, lemak dan serat kasar kulit kopi.

Kulit kopi segar memiliki kandungan nutrisi yang rendah, kandungan serat kasar yang tinggi dan zat anti nutrisi seperti kafein dan tanin. Oleh karena itu kulit kopi difermentasi menggunakan jamur Trichoderma viride untuk meningkatkan kandungan nutrisi kulit kopi seperti kandungan protein, lemak dan serat kasar dari kulit kopi tersebut sehingga kulit kopi terfermentasi dapat di jadikan bahan pakan yang berkualitas (Tilawati, 2016). Kapang Trichoderma viride telah digunakan dalam fermentasi beberapa bahan pakan terutama bagi limbah. Manfaat fermentasi dengan teknologi ini antara lain meningkatkan kandungan protein, menurunkan kandungan serat kasar, menurunkan kandungan tanin (Herviana, 2011).

Penelitian tentang fermentasi kulit buah kopi menggunakan jamur Aspergillus niger dapat menaikkan kandungan protein kasar dari 8,80\% menjadi $12,34 \%$ dan menurunkan kandungan serat kasar dari $18,2 \%$ menjadi $11,05 \%$ (Guntoro dan Yasa, 2005).Penggunaan jamur Trichoderma viride pada jerami padi terfermentasi dapat meningkatkan kandungan protein kasar dari 4,65\% menjadi $6,65 \%$ dan kandungan serat detergent asam dari $45,93 \%$ menjadi $52,62 \%$ (Supriyati dkk., 2010). Hasil penelitian menunjukkan bahwa fermentasi kulit kopi dengan menggunakan jamur Trichoderma dapat digunakan sebagai pengganti konsentrat karena kandungan Protein Kasar, 
Lemak Kasar dan Serat Kasar memenuhi syarat komposisi nutrisi yang diberikan kepada ternak (Tilawati, 2016). Penelitian ini bertujuan untuk pemanfaatan limbah kulit kopi menggunakan Trichoderma $s p$ untuk meningkatkan kualitas nutrisi dari limbah kulit kopi.

\section{METODE PENELITIAN}

\section{Alat}

Peralatan yang digunakan dalam pembuatan fermentasi pakan ternak dari limbah kulit kopi menggunakan Trichoderma yaitu: Gelas ukur, Timbangan digital, Timbangan duduk, Ember, Gembor, Plastik, Selotip.

\section{Bahan}

Bahan yang digunakan dalam pembuatan fermentasi pakan ternak dari limbah kulit kopi menggunakan Trichoderma yaitu: Trichoderma starter diperoleh dari produk komersil Kulit kopi (5 $\mathrm{kg})$, Air $(60 \%$ x $5 \mathrm{~kg}=3$ Liter untuk ciptakan kelembaban; $3 \%$ x $5 \mathrm{~kg}=1,5$ Liter untuk larutan), Tetes tebu ( $3 \% \times 1,5$ Liter $=$ $150 \mathrm{ml})$, Trichoderma cair $(1 \% \times 150 \mathrm{ml}=$ $1,5 \mathrm{ml})$. Perlakuan diulang sebanyak $3 \mathrm{kali}$ pembuatan diwaktu yang berbeda dan dibuat ulangan sebanyak 12 kantong plastik.

\section{Metode}

Menimbang $5 \mathrm{~kg}$ kulit kopi yang telah dihancurkan, selanjutnya Menyiram kulit kopi menggunakan 3 Liter air untuk menciptakan kelembaban $60 \%$. Kulit kopi dicampur dengan air hingga homogen. 150 ml tetes tebu ke dalam 1,5 Liter air, dilarutkan hingga homogen. 1,5 $\mathrm{ml}$ Trichoderma cair lalu dicampur dengan larutan air dan tetes tebu, diaduk hingga homogen dan larutan didiamkan selama 15 menit. Selanjutnya disiram pada kulit kopi hingga homogeny. Kulit kopi tersebut dimasukkan ke dalam plastik, masingmasing plastik sebanyak 500 gram. Kemasan dilubangi kecil-kecil (semi-anaerob). Memberi label yang berisi tanggal pembuatan dan no. urut kemasan (untuk memudahkan pengamatan). Menyimpannya di tempat yang sejuk, teduh dan terhindar dari sinar matahari langsung selama 7 hari.

\section{Variabel pengamatan}

Variable pengamtan meliputi kualitas fisik yang terdiri dari uji organoleptic dengan jumlah panelis sebanyak 12 mahasiswa yang meliputi tekstur, aroma, bau, ada dan tidaknya kontaminasi, $\mathrm{pH}$ menggunakan $\mathrm{pH}$ meter, dan uji analisis proksimat (Laboratorium Sentral, Universitas Muhammadiyah Malang). Hasil pengamatan selanjutnya dihitung rerata dan standard deviasi dan dibandingkan dengan hasil penelitian terdahulu (studi pustaka).

\section{HASIL DAN PEMBAHASAN}

\section{Kualitas Fisik Limbah Kulit Kopi Setelah Difermentasi Menggunakan Kapang Trichoderma}

Hasil pengamatan tentang kualitas fisik limbah kulit kopi setelah difermentasi menggunakan kapang Trichoderma (cair) dapat dilihat pada Tabel 1.

Tabel 1. Kualitas Fisik Limbah Kulit Kopi Setelah Difermentasi

\begin{tabular}{|c|c|c|c|c|c|c|c|c|c|c|c|c|c|c|c|c|c|c|}
\hline \multirow{2}{*}{$\begin{array}{c}\text { Kualitas } \\
\text { Fisik }\end{array}$} & \multicolumn{18}{|c|}{ Sampel ke- } \\
\hline & 1 & 2 & 3 & 4 & 5 & 6 & 7 & 8 & 9 & 10 & 11 & 12 & 13 & 14 & 15 & 16 & 17 & 18 \\
\hline Warna & 1 & 2 & 4 & 1 & 4 & 1 & 4 & 1 & 3 & 2 & 1 & 4 & 1 & 1 & 2 & 3 & 1 & 1 \\
\hline Tekstur & 2 & 2 & 2 & 2 & 1 & 4 & 2 & 2 & 2 & 2 & 3 & 1 & 3 & 1 & 1 & 2 & 2 & 2 \\
\hline $\mathrm{Bau}$ & 2 & 2 & 4 & 1 & 3 & 2 & 3 & 1 & 1 & 4 & 1 & 3 & 1 & 2 & 3 & 1 & 1 & 1 \\
\hline
\end{tabular}


Keterangan nilai:

\begin{tabular}{clll}
\hline Nilai & \multicolumn{1}{c}{ Ket. warna } & \multicolumn{1}{c}{ Ket. tekstur } & \multicolumn{1}{c}{ Ket. bau } \\
\hline 1 & Kuning kecoklatan & Sangat kasar & Asam segar \\
2 & Coklat & Kasar & Asam \\
3 & Coklat gelap & Sangat halus & Sedikit asam \\
4 & Gelap & Halus & Busuk \\
Hasil rerata & 1 (kuning kecoklatan) & 2 (kasar) & 1 (asam segar) \\
\hline
\end{tabular}

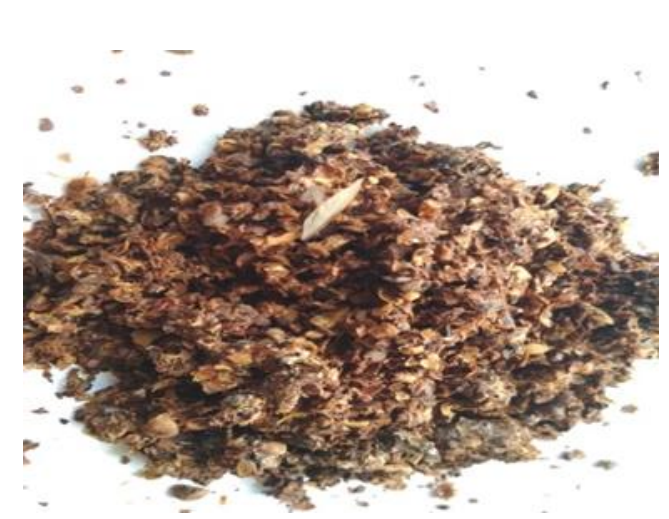

Gambar 1. Hasil fermentasi kulit Kopi selama 7 hari

Hasil pengamatan tentang kualitas fisik limbah kulit kopi setelah difermentasi menggunakan kapang Trichoderma (cair) dapat dilihat pada Tabel 1. Dari 18 sampel kulit kopi yang telah difermentasikan menggunakan kapang Trichoderma (cair) mayoritas berwarna kuning kecoklatan yaitu sebanyak 9 sampel. Tekstur yang kasar dominan pada kulit kopi hasil fermentasi menggunakan kapang Trichoderma (cair), yaitu sebanyak 11 dari 18 sampel. Sementara itu bau yang dominan pada kulit kopi hasil fermentasi yaitu berbau asam segar, sebanyak 8 dari 18 sampel.

Berdasarkan hasil percobaan warna limbah daun angsana yang diokulasi dengan Trichoderma sp pada lama inkubasi 7 hari menunjukkan warna dari tiga perlakuan sama yaitu berwarna coklat. Hasil penelitian dari Munawaroh dan Anggaraini (2017) sesuai dengan penelitian dari Prayuwidayati (2009) yang menyatakan bahwa warna jerami jagung yang diinokulasi dengan jamur Trichoderma sp pada lama inkubasi yang berbeda secara fisik menunjukkan bahwa mempunyai warna coklat keputihputihan. Bau limbah dari daun angsana yang diinokulasi dengan Trichoderma sp pada lama fermentasi yang sama menghasilkan bau yang sama yaitu aroma asam. Hal tersebut dikarenakan adanya aktivitas mikroba yang menyebabkan perubahan bau menjadi asam pada penyimpanan anaerob. Menurut Prasojo dkk (2013) menyatakan bahwa ada 4 kriteria untuk penilaian aroma dari fermentasi diantaranya yaitu sangat wangi, wangi, asam, dan bau tidak sedap. Sedangkan untuk tekstur dari daun angsana yang difermentasi dengan Trichoderma $s p$ ini teksturnya sama yaitu lembek. Fermentasi pakan menggunakan trichoderma dapat memecah fraksi selulosa yang ada dalam limbah pertanian (kulit kopi, daun angsana) karena proses fermentasi tersebut mensekresikan enzim selulase (Kodri dkk, 2013)

Menurut Billah, 2009 (dalam Pamungkas, F. B., dkk) pH juga berpengaruh terhadap aktifitas mikroba. Sebagian besar mikroba dapat tumbuh dengan baik pada $\mathrm{pH}$ antrara 6,5-7,5. Sedangkan Trichoderma hidup di rentang $\mathrm{pH} 4-8$. Hasil pengukuran $\mathrm{pH}$ dari 18 sampel kulit kopi yang telah difermentasikan menggunakan kapang Trichoderma (cair) diambil 3 sampel secara acak untuk ditentukan kadar pHnya. Penentuan kadar $\mathrm{pH}$ menggunakan $\mathrm{pH}$-meter seperti yang terlihat pada Gambar 1. Sampel yang diambil adalah sampel nomor 6, 7 dan 16 masing-masing memiliki $\mathrm{pH}$ sebesar 4, dan 5. Hal ini berarti mikroba Trichoderma dapat tumbuh pada kulit kopi tersebut dan diperoleh pemecahan sumber serat dari kulit kopi menjadi asam laktat ( indicator $\mathrm{pH}$ asam). 


\section{Kandungan Nutrisi (Analisis Proksimat) Kulit Kopi Setelah Difermentasi Menggunakan Kapang Trichoderma}

Berdasarkan Tabel 2, kandungan protein limbah kulit kopi yang difermentasi menggunakan Trichoderma pada penelitian yang dilaksanakan Tilawati, lebih tinggi dibandingkan dengan limbah kulit kopi yang difermentasi tanpa inokulen. Namun kandungan protein limbah kulit kopi yang difermentasi menggunakan Trichoderma pada penelitian ini (3) lebih rendah dibandingkan dengan limbah kulit kopi yang difermentasi tanpa inokulen (1). Hasil studi pustaka, Rizki dan Imsya, 2011 (dalam Tilawati, 2016) menyatakan bahwa jamur Trichoderma mampu memanfaatkan bahan organik yang terkandung dalam bahan pakan yang digunakan untuk dirombak serta dikonversikan sehingga terjadi peningkatan pada kandungan protein. Berdasarkan hasil pengujian Laboratorium untuk kualitas nutrisi kulit kopi sebelum difermentasi kandungan proteinnya sebesar $11,29 \%$ dan serak kasarnya 28, 13\%. Halini menunjukkan bahwa dari hasil penelitian terjadi kenaikan protein sebanyak $21 \%$, dan penurunan serat kasar sebesar $4 \%$.

Tabel 2. Perbandingan Kandungan Nutrisi (Analisis Proksimat) Limbah Kulit Kopi

\begin{tabular}{lccc}
\hline Sampel & PK(\%) & SK $(\%)$ & LK $(\%)$ \\
\hline 1 & $17,18^{*}$ & $29,14^{*}$ & $0,83^{*}$ \\
2 & $17,59^{*}$ & $27,74^{*}$ & $0,93^{*}$ \\
3 & 13,67 & 26,95 & 1,03 \\
4 & 11,29 & 28,13 & 24,84 \\
\hline
\end{tabular}

$$
\text { Selanjutnya Bagus }
$$

menyatakan bahwa Trichoderma merupakan jenis kapang yang mampu menghancurkan selulosa tingkat tinggi dan memiliki kemampuan mensintesis beberapa faktor esensial untuk melarutkan bagian selulosa yang terikat kuat dengan ikatan hidrogen. Dari penelitian yang dilakukan Tilawati, 2016 jamur Trichoderma mampu menurunkan kandungan serat kasar sebesar $1,40 \%$. Sementara itu dalam praktikum ini penggunaan Trichoderma mampu memberikan selisih (menurunkan) kandungan serat kasar sebesar $2.19 \%$, hal ini menunjukkan bahwa jamur Trichoderma mampu memecah ikatan serat kulit buah kopi selama proses fermentasi berlangsung. Hal ini sesuai dengan pendapat Yang et all., (2005) bahwa sebagian besar jamur dapat menghasilkan enzim ligninase dan enzim selulase, yaitu enzim yang dapat mengurai ikatan lignin dan selulosa. Hal ini didukung oleh Volk, 2004 (dalam Tilawati, 2016) menyatakan bahwa jamur Trichoderma sebagai penghasil enzim selulose lengkap untuk menghidrolisis selulosa dan kristal yang menyebabkan penurunan kandungan serat kasar.

Tabel 2 di atas menunjukkan bahwa kandungan lemak kasar cenderung lebih tinggi pada perlakuan fermentasi yang menggunakan jamur Trichoderma yaitu sebesar $0,93 \%$ pada penelitian yang dilakukan Tilawati dan sebesar $1,03 \%$ pada penelitian ini, serta cenderung lebih rendah pada perlakuan fermentasi tanpa penambahan inokulan yaitu sebesar $0,83 \%$. Hal ini menunjukkan bahwa jamur Trichoderma mampu menghasilkan enzim lipase selama proses fermentasi berlangsung. Hal ini didukung oleh Rarumangkay (2002), yang menyatakan bahwa selama proses fermentasi, terjadi reaksi oksidasireduksi yang menghasilkan energi sebagai donor dan akseptor elektron, serta terjadi perubahan kimiawi dan selanjutnya diubah oleh reaksi reduksi dengan katalis enzim.

Hasil penelitian yang diperoleh, kandungan lemak kasar sebesar $1,03 \%$ yaitu aman untuk pakan ternak. Kandungan lemak kasar yang tinggi pada bahan pakan ternak ruminansia dapat mengganggu proses fermentasi bahan pakan dalam rumen ternak. Hal ini didukung oleh Preston dan Leng (1987) serta Palmquist dan Jenkins (1980) menyatakan bahwa standar kandungan lemak kasar bahan pakan ternak ruminansia berkissar di bawah $5 \%$. 


\section{KESIMPULAN DAN SARAN}

\section{Kesimpulan}

Dari hasil penelitian teknologi fermentasi menggunakan kapang Trichoderma pada limbah kulit kopi yang telah dilaksanakan, diperoleh kesimpulan sebagai berikut:

1. Sampel kulit kopi yang telah difermentasikan menggunakan kapang Trichoderma (cair) dominan berwarna kuning kecoklatan, memiliki tekstur yang kasar dan berbau asam segar; $\mathrm{pH}$ pada kulit kopi hasil fermentasi berkisar antara 4.

2. Melalui analisis proksimat diperoleh hasil bahwa sampel kulit kopi yang telah difermentasikan menggunakan kapang Trichoderma (cair) memiliki kandungan protein sebesar 13,67\%, serat kasar sebesar 26,95\% dan lemak kasar 1,03\%.

\section{Saran}

Penelitian tentang kualitas fermentasi kulit kopi menggunakan Trichoderma sp selama 7 hari perlu adanya penelitian lebih lanjut untuk mengetahui efektivitasnya terhadap performance sapi potong.

\section{DAFTAR PUSTAKA}

Azwar A.B. 2012. Intensifikasi kopi jadi program unggulan baru. Media Perkebunan, 99, 16-17.

Bagus. 2011. Bioetanol dari limbah kulit kopi dengan fermentasi Fakultas Teknologi Industri, Universitas Pembangunan Nasional Veteran Jawa Timur.

Chet, I. 1987. Innovative approaches to plant diseases control. John Wiley and Sons, A Wiley-Interscience Publication, USA. pp. 11- 210.

Djajanegara A. dan P.Sitorus.1993. Problematika pemanfaatan limbah pertanian untuk makanan ternak. Jurnal Litbang.

Guntoro, S. dan I.M.R. Yasa. 2005.Pengaruh penggunaan limbah kopi terfermentasi terhadap produktivitas susu kambing. Prosiding Seminar Nasional Pemasyarakatan Inovasi Teknologi Revitalisasi Pertanian dan Pedesaan di Lahan Marginal. PSE, Bogor, p. 562565.

Herviana. 2011. Pengolahan kopi. Jurusan Teknologi Pertanian Fakultas Pertanian. Sumatra Utara.

Ismayadi, C.2000. Perkembangan teknologi pengolahan kopi arabika di indonesia.Warta Pusat Penelitian Kopi dan Kakao Indonesia, 16, 239-251.

Ismujianto, B.S., Aeny, N.T., dan Ginting C., 1996. Pengaruh jamur antagonis Trichoderma viridae dan kompos SCHL. F.sp Vanilae (Tucker) gordon penyebab penyakit busuk batang pada tanaman panili (Vanilla planifolia Andrews). Jurnal Penelitian Pertanian, $8 ; 86$.

Kodri, B.D, Agro., R, Yulianingsih. 2013. Pemanfaatan Enzim Selulase dari Trichoderma Reseei dan Aspergillus Niger sebagai Katalisator Hidrolisis Enzimatik Jerami Padi dengan Pretreatment Microwave. Jurnal Bioproses Komoditas Tropis. Vol 1. No. 1, April, 2013.

Munawaroh, F.Y dan Lina, A. 2017. Aplikasi Trichoderma sp Terhadap Kualitas Fermentasi Limbah Daun Angsana ( Pterocarpus indicus Wild). https://semnas.unikama.ac.id/lppm/pr osiding/2017/2.PANGAN\%20\&\%20T ERNAK/Febria\%20Yatimatul_Penelit ian_Pangan\%20dan\%20Ternak.pdf. Seminar nasional UNIKAMA. 
Prasojo, W., Suhartati F.M dan Rahayu, S. 2013. Pemanfaatan kulit singkong fermentasi menggunakan leuconostoc mesenteroides dalam pakan pengaruhnya terhadap n-nh3 dan vfa (in vitro). Jurnal Ilmiah Peternakan. 1(1):397-404.

Preston, T.R., and A.R. Leng. 1987. Matching ruminant production systems with available resourse in the tropics and sub-tropics. Penambil nook Armidale, New South Wales, Australia.

Rarumangkay, J. 2002. Pengaruh Fermentasi Isi Rumen Sapi oleh Trichoderma viride terhadap Kandungan Serat Kasar dan Energi Metabolis pada Ayam Broiler. Program Pasca Sarjana, UNPAD,Bandung.

Tilawati. 2016. Kandungan protein kasar, lemak kasar dan serat kasar limbah kulit kopi yang difermentasi menggunakan jamur Aspergiluus niger dan Trichoderma viride. [Internet]. [diunduh 19 Januari 2019]. Tersedia pada: https://core.ac.uk/ download/pdf/77626265.pdf.

Yang. J. S, H. L. Yuan, H. X. Wang and W. $X$ Chen. 2005. Purification and Characterization of Lignin Peroxidases from Penicillium decumbens P6. World Journal of Microbiology and Biotechnology 22 (4), 317-324. 